\title{
Sequential stress control and delayed support in deep shaft construction
}

\author{
Huanxin Liu ${ }^{1,2,3} \cdot$ Zhuoying $\operatorname{Tan}^{1} \cdot \mathrm{Xi} \mathrm{Wang}^{2,3} \cdot \mathrm{Xing}$ quan $\mathrm{Liu}^{2,3} \cdot$ Xingdong Zhao ${ }^{4} \cdot$ Yangyang $\mathrm{Li}^{4}$
}

Received: 3 June 2021 / Accepted: 6 January 2022 / Published online: 14 February 2022

(c) The Author(s) 2022

\begin{abstract}
In constructing hard rock mine deep shafts, the failure caused by high stress is a significant problem. A construction section extending from the $-930 \mathrm{~m}$ to $-1271 \mathrm{~m}$ level of a $1527 \mathrm{~m}$ deep shaft was selected as a case study. Q, RMR, and GSI rock mass quality classifications of the surrounding rock were obtained to determine the shaft's maximum unsupported sinking cycle height in different construction sections. The potential failure mode, failure zone shape, and failure depth of the surrounding rock shaft under high stress were then analyzed theoretically, empirically, and by numerical simulation, sequential stress control and delayed support technology was proposed according to the results. The temporary and permanent support timing parameters were calculated and verified by the empirical chart, numerical simulation, convergence-confinement theory, and theoretical formula. Results show that the surrounding rock in all the construction sections from -930 m to - $1271 \mathrm{~m}$ belongs to the mild or severely pressure squeezed strata. The potential failure mode is stress-controlled, and the failure zone of the surrounding rock is "ear" shaped. Temporary support strengthens the rock mass, improves the shear capacity of surrounding rock, and prevents the broken rock from falling but does not release stress. Permanent support, conversely, cannot bear the stress of surrounding rock. The stress and elastic strain energy in rock mass should be released to the greatest extent possible before installing permanent support; it is not advisable to install it too early. The time and cycle height of delayed permanent shaft support were comprehensively determined to be four days and $16 \mathrm{~m}$, respectively. The numerical simulation and safety factor proof show that the sequential stress control process effectively minimizes stress in surrounding rock and ensures long-term shaft stability.
\end{abstract}

Keywords Deep shaft $\cdot$ Sequential stress control $\cdot$ Delay support $\cdot$ High stress

\section{Introduction}

Communicated by Murat Karakus.

Huanxin Liu

ssdxmb@163.com

$\bowtie$ Zhuoying Tan markzhy_tan@163.com

1 University of Science and Technology Beijing, Beijing 100083, China

2 Deep Mining Laboratory of Shandong Gold Group, Laizhou 261442, Shandong, China

3 Research Centre On Underground Non-Coal Mine Ground Pressure Disasters Prevention of Shandong Province, Laizhou 261442, Shandong, China

4 Northeastern University, Shenyang 110819, Liaoning, China
The shaft is the throat of the underground mining production system. It is a significant piece of infrastructure, and its establishment is the most challenging project related to underground mine construction. Compared with a shallow shaft, the geological conditions and stress state of a deep shaft are more complex, especially under the action of strong excavation disturbance ( $\mathrm{Li}$ et al. 2013; Walton et al. 2018). Polytropic strata and stress conditions produce increasingly complicated mechanical response mechanisms and distinct response characteristics as depth increases (Mishra et al. 2017; Li et al. 2020; Zhang et al. 2018). To this effect, shallow-shaft design methods and construction technologies may not be directly applicable in deep-shaft engineering scenarios.

In deep hard rock engineering, with the in-situ stress increasing, substantial excavation and stress unloading cause rapid changes in local horizontal or vertical stress and higher stress concentration. Fracture, fragmentation, plastic expansion, rockburst, or other 
disasters may occur once the compression-shear stress borne by the surrounding rock exceeds its capacity (Zhou et al. 2015; Ren et al. 2020; Arshadnejad 2019). As a result, the geological environment of shaft-surrounding rock deteriorates. Deformation and failure are inelastic rather than simply controlled by the structural plane, especially as horizontal tectonic stress, blasting disturbance, and other nonlinear loads increasingly affect the system. Effective stress control and support design measures under high stress and strong excavation disturbance conditions are necessary for the long-term stability of deep shafts (Li et al. 2010). However, there is no universally accepted stress control technique for the construction process of hard rock deep shafts in metal mines. In soft rock shaft engineering, the "rigid resistance" method based on steel plates or high-strength concrete is generally adopted for shaft support (Yao et al. 2020) to resist high stress. Another support concept is called yielding or flexible support, which allows some deformation to occur in a controlled manner by the dissipation of deformation energy in order to reduce the ground pressure and cause the relaxation of ground stress, Ge 2020 developed a new flexible and yielding support under a weak and squeezing rock, it has an initial, intermediate and final layers, the intermediate layer between initial and final layers as a deformation gap which turns the system into highly flexible support, which helped control decline.

Several technical problems persist in constructing shafts more than $1200 \mathrm{~m}$ deep due to complex construction conditions such as high in-situ stress and induced stress, high water pressure, and high rock temperature. Unlike weak and large deformation rock conditions, high-stress hazards including rock failure and even rock burst events are highly problematic in hard rock mine (Sun et al. 2020; Wagner 2019). There is an urgent demand for a new technical system for stress control and support to ensure the long-term stability of deep shafts. This research proposes a sequential stress control and delayed support technology based on the rock-support interaction principle. The proposed method was developed using empirical, convergence-confinement theory, and numerical simulation information. Stress distribution and deformation are found to be controllable by improving existing construction technology. This method emphasizes the energy released in advance rather than after the support, it can help reduce the use of support material and maintain long-term stability in shafts more than $1200 \mathrm{~m}$ deep. They have been successfully applied in a $1527 \mathrm{~m}$ deep shaft in China, presented below as a case study.

\section{Project overview}

A new shaft under construction is located Xincheng-Jiaojia fault zone, Jiaodong Peninsula (Fig. 1). It has a designed diameter of $7.5 \mathrm{~m}$, the net diameter of $6.7 \mathrm{~m}$, head elevation of $+32.9 \mathrm{~m}$, bottom elevation of $-1494.1 \mathrm{~m}$, and total depth of $1527 \mathrm{~m}$. In the sinking process, the normal section is supported by $\mathrm{C} 25$ plain concrete with $300 \mathrm{~mm}$ thickness above $-622 \mathrm{~m}$ and $400 \mathrm{~mm}$ below $-622 \mathrm{~m}$. In the mine area, the main ore-controlling structure is the Jiaojia fault, derived from Houjia and Hexi faults (Huang et al. 2020) which jointly constitute the ore-controlling fault system. To master the in-situ stress distribution and provide a basis for shaft design, six measuring points from the $830 \mathrm{~m}$ to $1060 \mathrm{~m}$ depth were measured using the traditional hollow inclusion gauge method. After linear regression processing, regression curves including the maximum horizontal principal stress $\sigma_{\text {hmax }}$, minimum horizontal principal stress $\sigma_{\text {hmin }}$, and the vertical principal stress $\sigma_{v}$ were obtained with depth
Fig. 1 Location of the new designed shaft (a) and simplified geological map including Jiaojia fault (b) (modified from Huang et al. 2020)

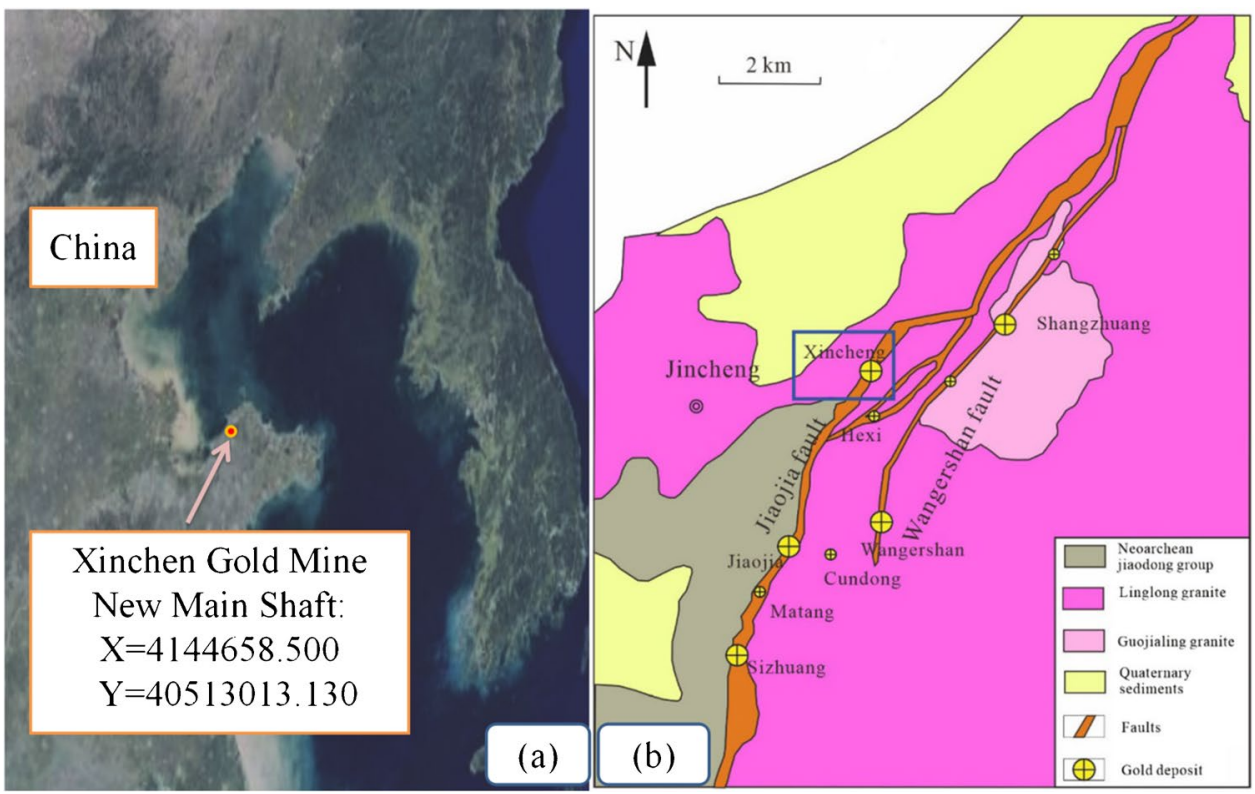




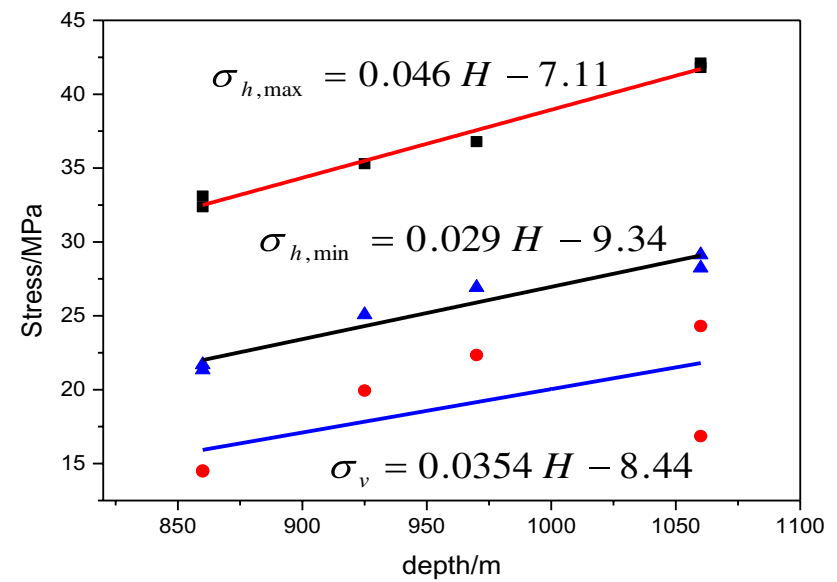

Fig. 2 Linear regression curve of measured in-situ stress

as shown Fig. 2. The maximum principal stress reaches 42.11 MPa at the measured $1060 \mathrm{~m}$ depth, and the regional stress field is controlled by horizontal tectonic stress.

In the shallow section construction, a mechanized rapid construction method was used. A sinking cycle time is usually 1 day and the sinking cycle height is $4 \mathrm{~m}$. It was divided into five construction stages: (a) drilling; (b) charging and blasting; (c) removing waste rock; (d) lining; (e) bottom cleaning, as shown in Fig. 3. This method is widely used, reducing the exposure time of surrounding rock, simplifying construction procedures, and ensuring construction quality and progress. However, the rockburst risk obviously increased as the excavation depth increased, especially after entering the depth of $-930 \mathrm{~m}$. In order to reduce the risk of rockburst, it was necessary to conduct stress control research. For this reason, the $930 \mathrm{~m}$ to $1271 \mathrm{~m}$ depth construction section was selected for stress control and delayed support research.

\section{Rock mass quality and stability evaluation}

Most support design and stability evaluation techniques are based on rock mass quality classification. The Barton rock mass quality classification is usually used in support design (Barton 1978; Barton et al. 1974; Bieniawski 1989) and the RMR rock mass quality is used in stability evaluation and parameter design. According to the engineering geological and hydrogeological condition, ore body occurrence condition, joint fracture information, in-situ stress measurement results, and rock physical and mechanical properties, the Barton rock mass quality $(\mathrm{Q})$ evaluation method was adopted in this study to classify engineered rock mass quality. The $\mathrm{Q}$ index value can be calculated as follows:

$\mathrm{Q}=\frac{\mathrm{RQD}}{\mathrm{J}_{\mathrm{n}}} \cdot \frac{\mathrm{J}_{\mathrm{r}}}{\mathrm{J}_{\mathrm{a}}} \cdot \frac{\mathrm{J}_{\mathrm{w}}}{\mathrm{SRF}}$

where $R Q D$ is the rock quality index; $J_{n}$ is the number of joint groups; $J_{r}$ is the joint roughness coefficient; $J_{a}$ is the joint alteration coefficient; $J_{w}$ is the joint water reduction coefficient; $S R F$ is the stress reduction factor. $R Q D / J_{n}$ represents the block size of rock mass; $J_{r} / J_{a}$ represents shear strength between blocks; $J_{w} / S R F$ represents the effects of water and other stresses on rock mass quality.

After field investigation ( Fig. 4) and laboratory testing, each rank index of Q, RMR, and GSI classification was determined and compared among shaft-surrounding rock sections between $-930 \mathrm{~m}$ and $-1271 \mathrm{~m}$ as shown in Table 1 .

According to the surrounding rock stability analysis chart (Fig. 5) established by a large sum of RMR rock mass classification results, if the RMR rating result is 63 , as the case showed, the corresponding unsupported sinking height is approximately $17 \mathrm{~m}$, and the stand-up time is more than 2 week; therefore, the unsupported sinking height and
Fig. 3 Mechanized rapid construction method: a drilling, b charging and blasting, c removing waste rock, $\mathbf{d}$ lining, $\mathbf{e}$ bottom cleaning

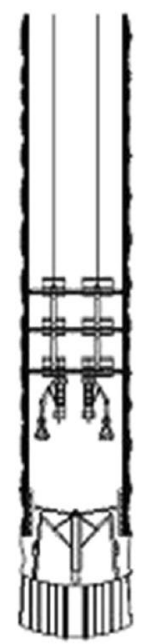

(a)

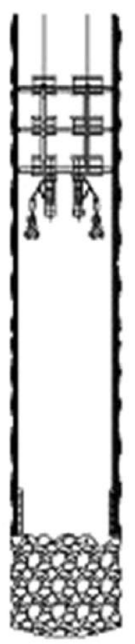

(b)

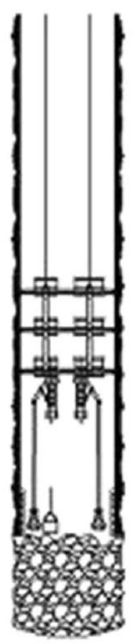

(c)

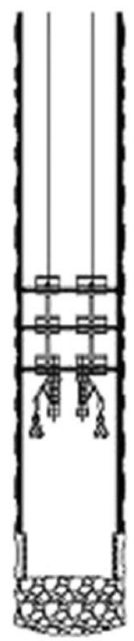

(d)

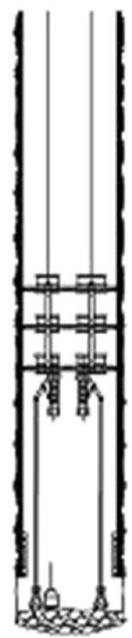

(e) 
Fig. 4 TV scans of boreholes (a) and core roughness in some sections (b)
Table 1 RMR, GSI, and Q rock quality classification results
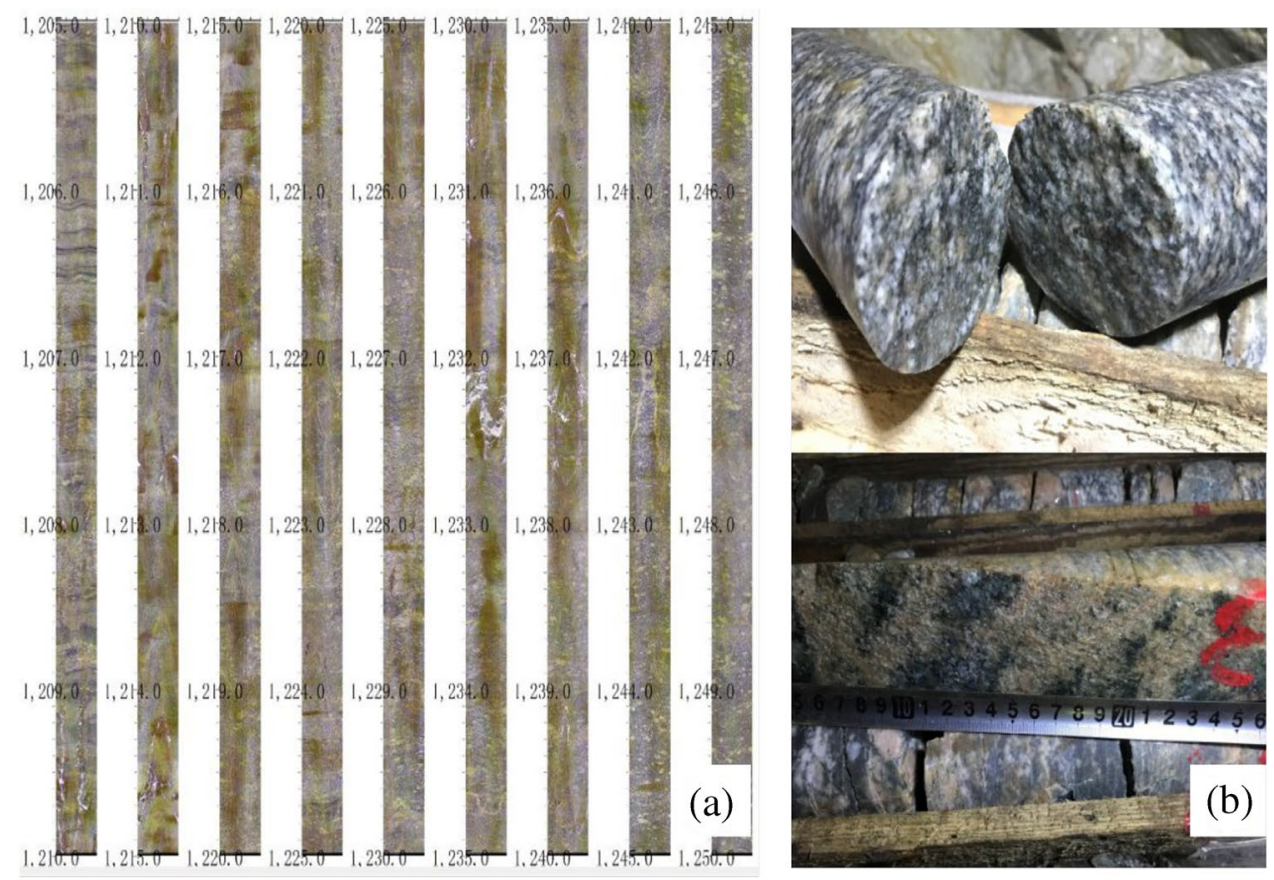

\begin{tabular}{|c|c|c|c|c|c|c|c|c|c|}
\hline \multirow[t]{2}{*}{ Construction section/m } & \multicolumn{6}{|c|}{ Grading index parameters } & \multirow[t]{2}{*}{ Q classification } & \multirow{2}{*}{$\begin{array}{l}\text { RMR } \\
\text { classifica- } \\
\text { tion }\end{array}$} & \multirow[t]{2}{*}{ GSI Score } \\
\hline & $R Q D$ & $J_{n}$ & $J_{r}$ & $J_{a}$ & $J_{w}$ & $S R F$ & & & \\
\hline$-930.0 \sim-972.0$ & 86 & 6 & $1 \sim 1.5$ & 1 & 1.0 & 20 & 1.1/IV & 69/II & 70 \\
\hline$-972.0 \sim-987.0$ & 76 & 9 & $1 \sim 1.5$ & 1 & 1.0 & 20 & $0.6 / \mathrm{IV}$ & 69/II & 65 \\
\hline$-987.0-1050.0$ & 51 & 9 & $1 \sim 1.5$ & 1 & 1.0 & 20 & $0.4 / \mathrm{IV}$ & 65/II & 65 \\
\hline$-1050.0 \sim-1073.0$ & 71 & 6 & $1 \sim 1.5$ & 1 & 1.0 & 20 & $0.9 / \mathrm{IV}$ & 65/II & 65 \\
\hline$-1073.0 \sim-1102.0$ & 52 & 6 & $1 \sim 1.5$ & 1 & 1.0 & 20 & $0.7 / \mathrm{IV}$ & 63/II & 65 \\
\hline$-1102.0 \sim-1153.0$ & 80 & 6 & $1 \sim 1.5$ & 1 & 1.0 & 20 & $1.0 / \mathrm{IV}$ & 69/II & 65 \\
\hline$-1153.0 \sim-1207.0$ & 77 & 9 & $1 \sim 1.5$ & 1 & 1.0 & 20 & $0.6 / \mathrm{IV}$ & 67/II & 65 \\
\hline$-1207.0 \sim-1250.0$ & 87 & 9 & $1 \sim 1.5$ & 1 & 1.0 & 20 & $0.7 / \mathrm{IV}$ & 69/II & 70 \\
\hline$-1250.0 \sim-1271.0$ & 68 & 9 & $1 \sim 1.5$ & 1 & 1.0 & 20 & $0.6 / \mathrm{IV}$ & $67 / \mathrm{II}$ & 65 \\
\hline
\end{tabular}

stand-up time can be determined primarily as Table 2 by Fig. 5, which demonstrate that it allows improving the height without lining immediately to $17-20 \mathrm{~m}$ and maintains the stability during shaft sinking.

\section{Deep shaft failure analysis}

\section{Failure mode and failure zone shape of surrounding rock}

The failure mode of surrounding rock in an underground excavation project can be divided into structural-plane controlled, stress controlled, and the conversion between these two types. Once a circular shaft is excavated, the redistributed two-dimensional (2D) stress in the plastic zone can be calculated by Eq. (2)-(3) ( Zhang et al. 2010). Here, we define a stability coefficient $\mathrm{N}$ by Eq. (4) ( Bhasin and Grimstad 1996) to describe the stress state after excavation and judge the shaft's potential failure mode. If $1<\mathrm{N}<5$, the judgment is mild squeezing rock pressure; if $\mathrm{N}>5$, it is heavy squeezing rock pressure. Table 3 gives more detailed information.

$\sigma_{r}^{(p)}=\left(p_{i}+c \cot \varphi\right)\left(\frac{r}{a}\right)^{\frac{2 \sin \varphi}{1-\sin \varphi}}-c \cot \varphi$

$\sigma_{r}^{(p)}=\left(p_{i}+c \cot \varphi\right)\left(\frac{r}{a}\right)^{\frac{2 \sin \varphi}{1-\sin \varphi}} \frac{1+\sin \varphi}{1-\sin \varphi}-c \cot \varphi$ 


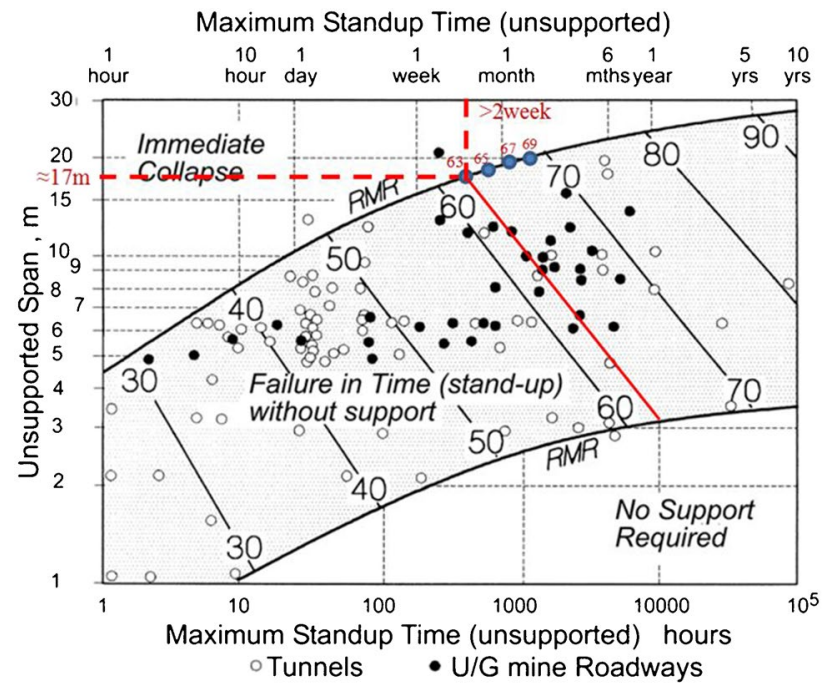

Fig. 5 Shaft stability analysis chart based on RMR results (Bieniawski 1989)

Table 2 Shaft stability parameters from $-930 \mathrm{~m}$ to $-1271 \mathrm{~m}$

\begin{tabular}{lllll}
\hline Construction section/m & RMR & $\begin{array}{l}\text { Sink- } \\
\text { ing cycle } \\
\text { height/m }\end{array}$ & $\begin{array}{l}\text { Unsup- } \\
\text { ported } \\
\text { height/m }\end{array}$ & $\begin{array}{l}\text { Stand- } \\
\text { up time/ } \\
\text { week }\end{array}$ \\
\hline$-930 \mathrm{~m} \sim-972 \mathrm{~m}$ & 69 & 4 & $\approx 20$ & $>2$ \\
$-972 \mathrm{~m} \sim-987 \mathrm{~m}$ & 69 & 4 & $\approx 20$ & $>2$ \\
$-987 \mathrm{~m} \sim-1050 \mathrm{~m}$ & 65 & 4 & $\approx 18$ & $>2$ \\
$-1050 \mathrm{~m} \sim-1073 \mathrm{~m}$ & 65 & 4 & $\approx 18$ & $>2$ \\
$-1073 \mathrm{~m} \sim-1102 \mathrm{~m}$ & 63 & 4 & $\approx 17$ & $>2$ \\
$-1102 \mathrm{~m} \sim-1153 \mathrm{~m}$ & 69 & 4 & $\approx 20$ & $>2$ \\
$-1153 \mathrm{~m} \sim-1207 \mathrm{~m}$ & 67 & 4 & $\approx 19$ & $>2$ \\
$-1207 \mathrm{~m} \sim-1250 \mathrm{~m}$ & 69 & 4 & $\approx 20$ & $>2$ \\
$-1250 \mathrm{~m} \sim-1271 \mathrm{~m}$ & 67 & 4 & $\approx 19$ & $>2$ \\
\hline
\end{tabular}

$N=\frac{\sigma_{\theta \max }}{\sigma_{\text {cmass }}}$

where $\sigma_{r}^{(P)}$ is the radial stress in the plastic zone, MPa; $\sigma_{\theta}{ }^{(P)}$ is the tangential stress in the plastic zone, $\mathrm{MPa} ; c$ is the cohesion, $\mathrm{MPa} ; \varphi$ is the internal friction angle, ${ }^{\circ} ; p_{i}$ is the supporting reaction pressure, $\mathrm{MPa} ; a$ is the shaft radius, $\mathrm{m} ; r$ is the distance from the center of the shaft, $\mathrm{m} ; \sigma_{\theta \max }$ is maximum tangential stress, $\mathrm{MPa} ; \sigma_{\text {cmass }}$ is rock mass strength, MPa.

Table 3 shows the $\mathrm{N}$ index value and the judging results of strata stress state, both the Hoek-Brown and rock mechanical parameters were calculated by RMR rating result and Hoek-Brown empirical formula (Lin et al 2017). It shows that the stress state is mild squeezing or heavy squeezing, so the potential failure mode of each construction section from -930 to $-1271 \mathrm{~m}$ is stress controlled. The failure zone shape of the shaft-surrounding rock can be divided into three types: ear failure, oval failure, and butterfly failure. Previous studies (Martin and Chandler 1994) have shown that when the failure zone shape of surrounding rock is non-butterfly, the average plastic zone radius under asymmetric stress is consistent with the plastic zone radius under hydrostatic pressure; this equates to the average asymmetric stress. It is reasonable to simplify the design process of shaft support when the water pressure is used as the stress boundary to draw the characteristic curve of the surrounding rock. As shown in Fig. 6, shaft failure zone shape can be judged according to different normalized mean stress $\left(\sigma_{1}+\sigma_{2}\right) / 2 \sigma_{c}{ }^{*}$ and normalized deviation stress $\left(\sigma_{1}-\sigma_{2}\right) / 2 \sigma_{\mathrm{c}}{ }^{*}$ values, $\sigma_{\mathrm{c}}{ }^{*}$ is called uniaxial compressive field strength, which is assumed to approximately $0.5 \sigma_{\mathrm{c}}$. The results demonstrate that the failure zone shape at all construction sections of shaft is "ear" type (Table 4).

\section{Failure depth analysis}

The Hoek-Brown strength criterion and Phase2 numerical simulation software were adopted to analyze the shaft damage zone distribution and its depth as shown in Fig. 7.

The depth of failure in brittle rock depends on stress (induced by excavation relative to uniaxial compressive strength $\sigma_{c}$ ), lateral pressure coefficient $\sigma_{1} / \sigma_{3}$, rock mass structure, formed shape after excavation, and dynamic stress increment induced by a distant micro-earthquake, $\Delta \sigma_{\mathrm{d}}$. An empirical relationship for the depth of failure around a shaft was established in a previous study (Martin et al.1999), given as Eq. (5)-(6).

$\frac{d_{f}}{a}=1.25 \frac{\sigma_{\max }}{\sigma_{c}}-0.51$

$\sigma_{\max }=3 \sigma_{1}-\sigma_{3}$

where $d_{f}$ is the failure depth of shaft-surrounding rock, $\mathrm{m} ; a$ is the shaft excavation radius, $\mathrm{m} ; \sigma_{c}$ is the uniaxial compressive strength of rock, $\mathrm{MPa} ; \sigma_{1}$ is the maximum principal stress, MPa; $\sigma_{3}$ is the minimum principal stress, MPa.

The failure depth of shaft-surrounding rock obtained from the above two methods is shown in Table 5. Compared with the numerical simulation method, the failure depth calculated by the empirical method is more extensive.

\section{Sequential stress control and delayed support}

Under high-stress condition, shaft excavation often causes stress redistribution and elastic strain energy accumulation in surrounding rock. If the energy accumulated in the rock 
Table 3 Geological information and failure mode analysis of shaft from -930 to $-1271 \mathrm{~m}$

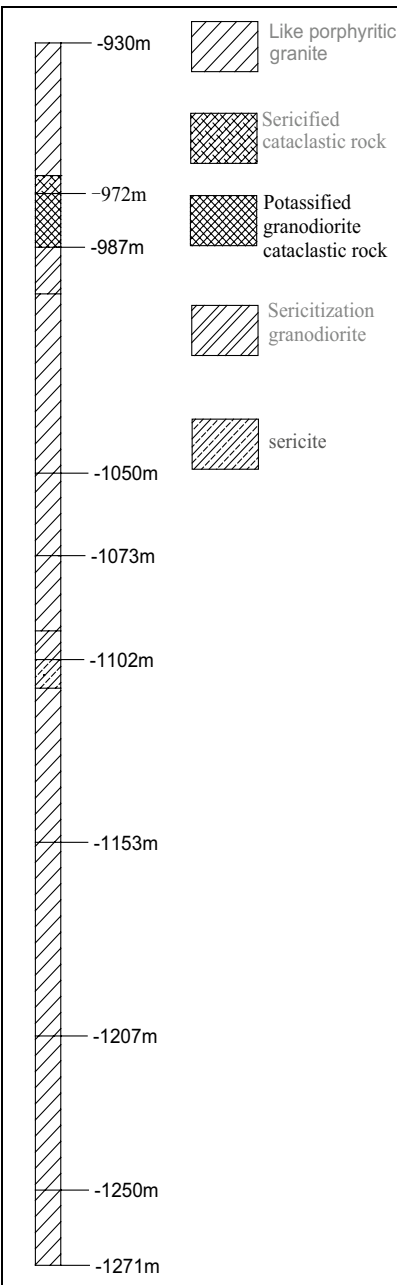

Depth: $930-972 \mathrm{~m} ; \mathrm{N}: 4.74 \sim 4.94$; Stress state: Mild squeezing rock pressure

Hoek Brown parameter: $m_{b}=4.863, s=0.016, a=0.501$

rock mass mechanical parameters: $c=7.28 \mathrm{Ma}, \varphi=39.61^{\circ}, \sigma_{\text {cmass }}=10.50 \mathrm{MPa}$

Depth: 972-987m; N:4.94 7.18 ; Stress state: Heavy squeezing rock

pressure.

Hoek Brown parameter: $m_{b}=3.611, s=0.005, a=0.502$

rock mass mechanical parameters: $c=6.55 \mathrm{Ma}, \varphi=37.08^{\circ}, \sigma_{\text {cmass }}=7.16 \mathrm{MPa}$

Depth: $987-1050 \mathrm{~m} ; \mathrm{N}: 7.18 \sim 7.75$; Stress state: Heavy squeezing rock pressure

Hoek Brown parameter: $m_{b}=3.611, s=0.005, a=0.502$

rock mass mechanical parameters: $c=6.55 \mathrm{Ma}, \varphi=37.08^{\circ}, \sigma_{\text {cmass }}=7.16 \mathrm{MPa}$

Depth: $1050-1073 \mathrm{~m} ; \mathrm{N}: 7.75 \sim 7.90$; Stress state: Heavy squeezing rock pressure

Hoek Brown parameter: $\mathrm{m}_{\mathrm{b}}=3.611, \mathrm{~s}=0.005, \mathrm{a}=0.502$

rock mass mechanical parameters: $c=6.55 \mathrm{Ma}, \varphi=37.08^{\circ}, \sigma_{\text {cmass }}=7.16 \mathrm{MPa}$

Depth:1073-1102m; N:7.90 8.12;Stress state: Heavy squeezing rock

pressure

Hoek Brown parameter: $m_{b}=3.611, s=0.005, a=0.502$

rock mass mechanical parameters $c=6.55 \mathrm{Ma}, \varphi=37.08^{\circ}, \sigma_{\text {cmass }}=7.16 \mathrm{MPa}$

Depth:1102-1153m; N:8.12-8.57;Stress state: Heavy squeezing rock

pressure

Hoek Brown parameter: $m_{b}=3.611, s=0.005, a=0.502$

rock mass mechanical parameters: $c=6.55 \mathrm{Ma}, \varphi=37.08^{\circ}, \sigma_{\text {cmass }}=7.16 \mathrm{MPa}$

Depth: 1153-1207m; N:8.57-9.03;Stress state: Heavy squeezing rock pressure

Hoek Brown parameter: $m_{b}=3.611, s=0.005, a=0.502$

rock mass mechanical parameters: $c=6.55 \mathrm{Ma}, \varphi=37.08^{\circ}, \sigma_{\text {cmass }}=7.16 \mathrm{MPa}$

Depth: 1207-1250m; N:9.03-9.40; Stress state: Heavy squeezing rock pressure

Hoek Brown parameter: $m_{b}=3.611, s=0.005, a=0.502$

rock mass mechanical parameters: $c=6.55 \mathrm{Ma}, \varphi=37.08^{\circ}, \sigma_{\text {cmass }}=7.16 \mathrm{MPa}$

Depth: $1250-1271 \mathrm{~m} ; \mathrm{N}: 9.40-9.57 ;$ Stress state: Heavy squeezing rock pressure

Hoek Brown parameter: $m_{b}=3.611, s=0.005, a=0.502$

rock mass mechanical parameters: $c=6.55 \mathrm{Ma}, \varphi=37.08^{\circ}, \sigma_{\text {cmass }}=7.16 \mathrm{MPa}$

mass exceeds its storage capacity, instability or rock bursts may occur (Yi et al. 2020; Jiang et al. 2010). The energy accumulated in the rock mass should be released before the permanent support is installed for stress control. In the construction of a hard rock deep shaft, an crucial supporting concept is that it is not usually the concrete lining that bears the stress but the surrounding rock itself.

This study developed a sequential stress control method that mainly focuses on flexible components such as bolts and steel mesh for early support after increasing the sinking 
Fig. 6 Determinant chart of failure form of shaft-surrounding rock (Martin et al.1999)
Table 4 Results of stress normalization of surrounding rock and failure zone shape judgment

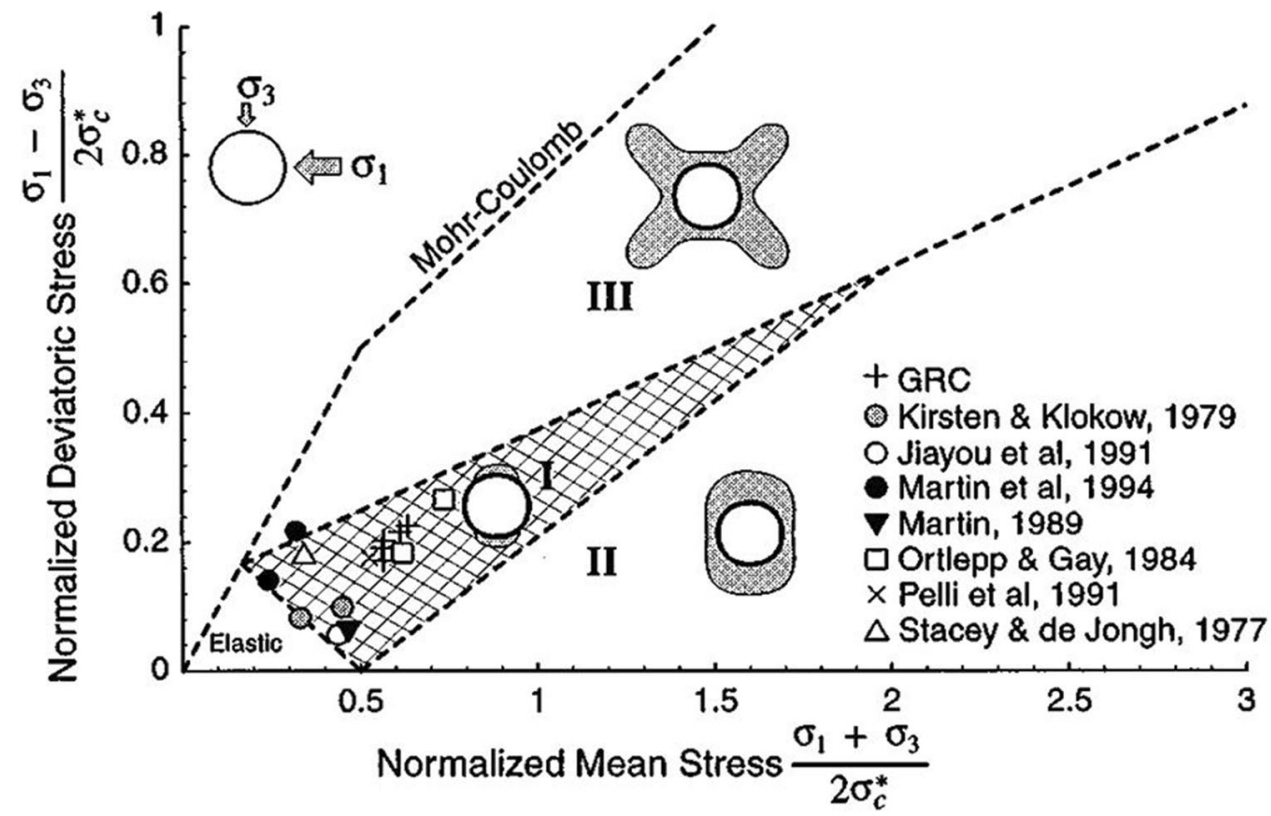

\begin{tabular}{lllllll}
\hline Construction Section/m & $\sigma_{1}$ & $\sigma_{3}$ & $\sigma_{\mathrm{c}}$ & $\begin{array}{l}\text { Normalized } \\
\text { deviatoric stress }\end{array}$ & $\begin{array}{l}\text { Normalized } \\
\text { average stress }\end{array}$ & $\begin{array}{l}\text { Judge- } \\
\text { ment } \\
\text { results }\end{array}$ \\
\hline$-930.0 \sim-972.0$ & 37.60 & 18.24 & 102.5 & 0.18 & 0.55 & $\mathrm{I}$ \\
$-972.0 \sim-987.0$ & 38.30 & 19.07 & 102.5 & 0.19 & 0.56 & $\mathrm{I}$ \\
$-987.0-1050.0$ & 41.19 & 20.20 & 102.5 & 0.20 & 0.61 & $\mathrm{I}$ \\
$-1050.0 \sim-1073.0$ & 42.25 & 21.44 & 102.5 & 0.20 & 0.62 & $\mathrm{I}$ \\
$-1073.0 \sim-1102.0$ & 43.58 & 22.20 & 102.5 & 0.21 & 0.64 & $\mathrm{I}$ \\
$-1102.0 \sim-1153.0$ & 45.93 & 23.36 & 102.5 & 0.22 & 0.68 & $\mathrm{I}$ \\
$-1153.0 \sim-1207.0$ & 48.41 & 24.88 & 102.5 & 0.23 & 0.72 & $\mathrm{I}$ \\
$-1207.0 \sim-1250.0$ & 50.39 & 26.29 & 102.5 & 0.24 & 0.75 & $\mathrm{I}$ \\
$-1250.0 \sim-1271.0$ & 51.36 & 27.21 & 102.5 & 0.24 & 0.77 & $\mathrm{I}$ \\
\hline
\end{tabular}

Fig. 7 Distribution of plastic zone during the construction section of $-1207 \mathrm{~m}$ to $-1250 \mathrm{~m}$ (a) and $-1250 \mathrm{~m}$ to $-1271 \mathrm{~m} \mathrm{(b)}$

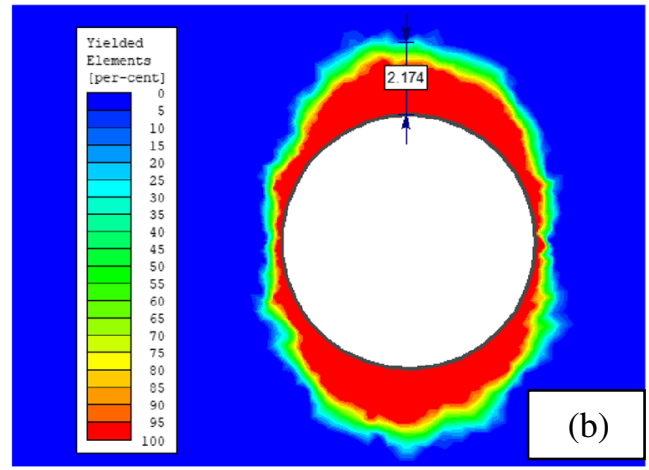

b)

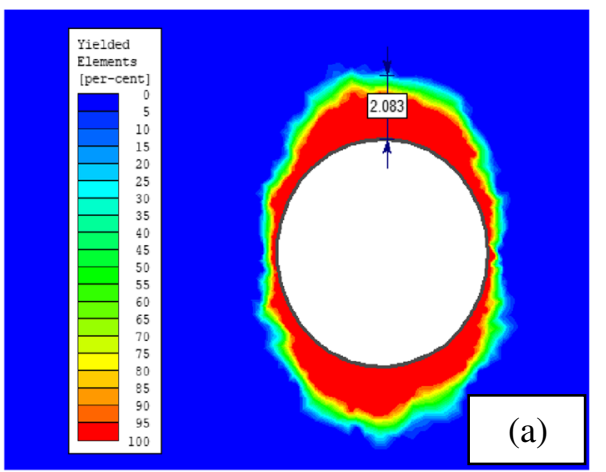

cycles without lining them immediately. It allows enough time for the surrounding rock to release stress before the concrete lining is installed, which minimizes stress to ensure long-term stability. The key to this approach is the proper 
Table 5 Failure depth calculation results around shaft in surrounding rocks

\begin{tabular}{|c|c|c|c|c|c|}
\hline Construction Section/m & Shaft radius $/ \mathrm{m}$ & $\begin{array}{l}\text { Maximum tangential } \\
\text { stress } / \mathrm{MPa}\end{array}$ & $\begin{array}{l}\text { Uniaxial compressive } \\
\text { strength /MPa }\end{array}$ & $\begin{array}{l}\text { Numerical simulation } \\
\mathrm{method} / \mathrm{m}\end{array}$ & $\begin{array}{l}\text { Empirical } \\
\text { method } / \mathrm{m}\end{array}$ \\
\hline$-930 \sim-972$ & 3.75 & 91.67 & 102.5 & 1.29 & 2.28 \\
\hline$-972 \sim-987$ & 3.75 & 94.78 & 102.5 & 1.82 & 2.42 \\
\hline$-987 \sim-1050$ & 3.75 & 99.03 & 102.5 & 1.96 & 2.62 \\
\hline$-1050 \sim-1073$ & 3.75 & 103.71 & 102.5 & 2.08 & 2.83 \\
\hline$-1073 \sim-1102$ & 3.75 & 106.55 & 102.5 & 2.01 & 2.96 \\
\hline$-1102 \sim-1153$ & 3.75 & 110.91 & 102.5 & 2.14 & 3.16 \\
\hline$-1153 \sim-1207$ & 3.75 & 116.63 & 102.5 & 2.08 & 3.42 \\
\hline$-1207 \sim-1250$ & 3.75 & 121.92 & 102.5 & 2.17 & 3.66 \\
\hline$-1250 \sim-1271$ & 3.75 & 125.40 & 102.5 & 2.01 & 3.82 \\
\hline
\end{tabular}

selection of lining time and sinking bench height with delayed permanent support.

\section{Temporary support}

We choose the construction section of $-930 \mathrm{~m}$ to $-1271 \mathrm{~m}$ in the new main shaft as a case study. The resin bolt and seam pipe bolt with adequate deformation ability were selected as temporary support material. Metal mesh and a bimetal bar were selected to prevent loose rock from falling, as shown in Fig. 8. The temporary support mainly serves to release dilatancy pressure and control loose pressure in rock mass.

According to the failure depth calculation results, Q and RMR rock mass quality classification results and their support chart (Rahim and Mohamad 2019; Kaya and Tarak, 2021), different support parameters, including bolt length and bolt spacing, are compared in Table 6 . Table 6 shows the primary selection results of support parameters, the bolt length is chosen according to the simulation results, and the bolt spacing is chosen by the Q rock quality index and its support chart.

The final designed bolt parameters were confirmed as $2.5 \mathrm{~m}$ in length with $1.5 \mathrm{~m}$ spacing at all construction sections to ensure the support safety. The bolts were installed horizontally in a circular distribution in the surrounding rock, 16 bolts in each row, and the row spacing and hole bottom spacing were $1.5 \mathrm{~m}$. The steel shape is HRB500 and $22 \mathrm{~mm}$ in diameter. After installing the bolt, the pressure in shaft-surrounding rock was unloaded through sequential stress control, then $400 \mathrm{~mm} \mathrm{C} 25$ concrete lining was applied. The support effect after installing bolts was simulated, as shown in Fig. 9.

As shown in Fig. 9, the designed bolt length is $2.5 \mathrm{~m}$ but the simulated failure depths are $1.78 \mathrm{~m}$ and $1.84 \mathrm{~m}$, which is smaller than the designed support bolt length whether it contains a structure plane or not. Therefore, the designed parameters meet the requirements for shaftsurrounding rock support.

\section{Timing determination for permanent support}

It is difficult to determine a reasonable sinking height and deformation of shaft for releasing stress in surrounding rock to an acceptable level for the purpose of sequential stress control. In this study, the convergence-confinement theory ( Manuel et al. 2019) was used to determine the proper time for permanent support. As shown in Fig. 10, the deformation characteristic curve (GRC) of surrounding rock, longitudinal section deformation characteristic curve (LDP) of surrounding rock, and support characteristic curve for concrete (PSCC) (400 mm, C25) are established by Eq. (7)-(9).
Fig. 8 Temporary support material of shaft: $\mathbf{a}$ resin bolt, $\mathbf{b}$ bimetal bar, c metal mesh
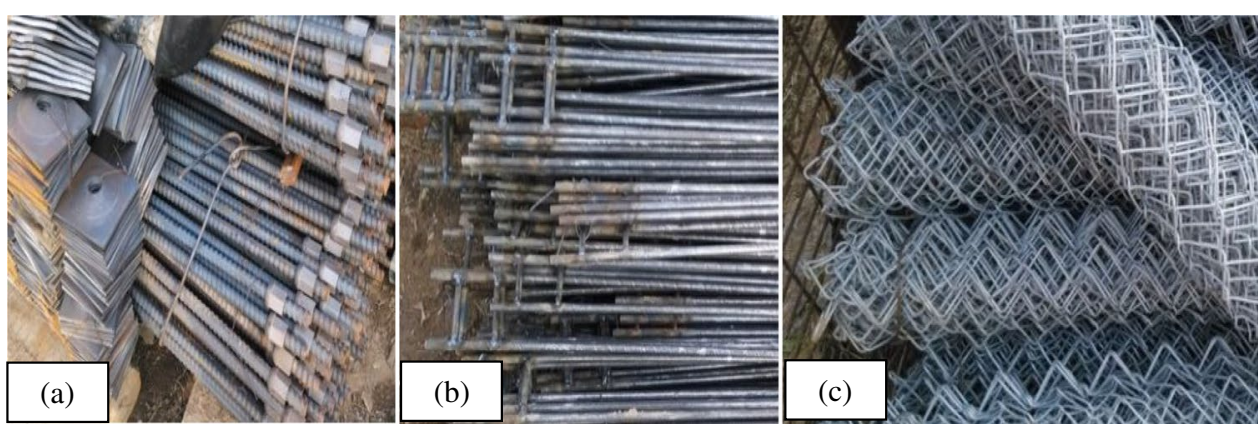
Table 6 Comparison of temporary support parameters and primary selection

\begin{tabular}{|c|c|c|c|c|}
\hline Construction Section/m & Rock quality index & Failure depth & $\begin{array}{l}\text { Support parameters determined by } \\
\text { support chart }\end{array}$ & $\begin{array}{l}\text { Primary selection } \\
\text { results of support } \\
\text { parameters }\end{array}$ \\
\hline$-930.0 \mathrm{~m} \sim-972.0 \mathrm{~m}$ & $\begin{array}{l}\mathrm{Q}=1.1 \\
\mathrm{RMR}=74\end{array}$ & $\begin{array}{l}\text { Simulation: } 1.29 \mathrm{~m} \\
\text { empirical method: } 2.28 \mathrm{~m}\end{array}$ & $\begin{array}{l}\mathrm{L}=3.2 \mathrm{~m} ; \mathrm{SC}=\mathrm{SL}=1.7 \mathrm{~m} \sim 2.1 \mathrm{~m} \\
\mathrm{~L}=3.0 \mathrm{~m} ; \mathrm{SC}=\mathrm{SL}=2.5 \mathrm{~m}\end{array}$ & $\begin{array}{l}\mathrm{L}=1.5 \mathrm{~m} \\
\mathrm{SC}=\mathrm{SL}=1.7 \mathrm{~m}\end{array}$ \\
\hline$-972.0 \mathrm{~m} \sim-987.0 \mathrm{~m}$ & $\begin{array}{l}\mathrm{Q}=0.6 \\
\mathrm{RMR}=74\end{array}$ & $\begin{array}{l}\text { Simulation: } 1.29 \mathrm{~m} \\
\text { empirical method: } 2.42 \mathrm{~m}\end{array}$ & $\begin{array}{l}\mathrm{L}=3.2 \mathrm{~m} ; \mathrm{SC}=\mathrm{SL}=1.5 \mathrm{~m} \sim 1.7 \mathrm{~m} \\
\mathrm{~L}=3.0 \mathrm{~m} ; \mathrm{SC}=\mathrm{SL}=2.5 \mathrm{~m}\end{array}$ & $\begin{array}{l}\mathrm{L}=1.5 \mathrm{~m} \\
\mathrm{SC}=\mathrm{SL}=1.5 \mathrm{~m}\end{array}$ \\
\hline$-987.0 \mathrm{~m} \sim-1050.0 \mathrm{~m}$ & $\begin{array}{l}\mathrm{Q}=0.4 \\
\mathrm{RMR}=70\end{array}$ & $\begin{array}{l}\text { Simulation: } 1.82 \mathrm{~m} \\
\text { empirical method: } 2.62 \mathrm{~m}\end{array}$ & $\begin{array}{l}\mathrm{L}=3.2 \mathrm{~m} ; \mathrm{SC}=\mathrm{SL}=1.5 \mathrm{~m} \\
\mathrm{~L}=3.0 \mathrm{~m} ; \mathrm{SC}=\mathrm{SL}=2.5 \mathrm{~mm}\end{array}$ & $\begin{array}{l}\mathrm{L}=2.0 \mathrm{~m} \\
\mathrm{SC}=\mathrm{SL}=1.5 \mathrm{~m}\end{array}$ \\
\hline$-1050.0 \mathrm{~m} \sim-1073.0 \mathrm{~m}$ & $\begin{array}{l}\mathrm{Q}=0.9 \\
\mathrm{RMR}=70\end{array}$ & $\begin{array}{l}\text { Simulation: } 1.96 \mathrm{~m} \\
\text { empirical method: } 2.83 \mathrm{~m}\end{array}$ & $\begin{array}{l}\mathrm{L}=3.2 \mathrm{~m} ; \mathrm{SC}=\mathrm{SL}=1.5 \mathrm{~m} \sim 1.7 \mathrm{~m} \\
\mathrm{~L}=3.0 \mathrm{~m} ; \mathrm{SC}=\mathrm{SL}=2.5 \mathrm{~mm}\end{array}$ & $\begin{array}{l}\mathrm{L}=2.0 \mathrm{~m} \\
\mathrm{SC}=\mathrm{SL}=1.5 \mathrm{~m}\end{array}$ \\
\hline$-1073.0 \mathrm{~m} \sim-1102.0 \mathrm{~m}$ & $\begin{array}{l}\mathrm{Q}=0.7 \\
\mathrm{RMR}=68\end{array}$ & $\begin{array}{l}\text { Simulation: } 2.08 \mathrm{~m} \\
\text { empirical method: } 2.96 \mathrm{~m}\end{array}$ & $\begin{array}{l}\mathrm{L}=3.2 \mathrm{~m} ; \mathrm{SC}=\mathrm{SL}=1.5 \mathrm{~m} \sim 1.7 \mathrm{~m} \\
\mathrm{~L}=3.0 \mathrm{~m} ; \mathrm{SC}=\mathrm{SL}=2.5 \mathrm{~m}\end{array}$ & $\begin{array}{l}\mathrm{L}=2.5 \mathrm{~m} \\
\mathrm{SC}=\mathrm{SL}=1.5 \mathrm{~m}\end{array}$ \\
\hline$-1102.0 \mathrm{~m} \sim-1153.0 \mathrm{~m}$ & $\begin{array}{l}\mathrm{Q}=1.0 \\
\mathrm{RMR}=74\end{array}$ & $\begin{array}{l}\text { Simulation: } 2.01 \mathrm{~m} \\
\text { empirical method: } 3.16 \mathrm{~m}\end{array}$ & $\begin{array}{l}\mathrm{L}=3.2 \mathrm{~m} ; \mathrm{SC}=\mathrm{SL}=1.7 \mathrm{~m} \\
\mathrm{~L}=3.0 \mathrm{~m} ; \mathrm{SC}=\mathrm{SL}=2.5 \mathrm{~m}\end{array}$ & $\begin{array}{l}\mathrm{L}=2.5 \mathrm{~m} \\
\mathrm{SC}=\mathrm{SL}=1.7 \mathrm{~m}\end{array}$ \\
\hline$-1153.0 \mathrm{~m} \sim-1207.0 \mathrm{~m}$ & $\begin{array}{l}\mathrm{Q}=0.6 \\
\mathrm{RMR}=72\end{array}$ & $\begin{array}{l}\text { Simulation: } 2.14 \mathrm{~m} \\
\text { empirical method: } 3.42 \mathrm{~m}\end{array}$ & $\begin{array}{l}\mathrm{L}=3.2 \mathrm{~m} ; \mathrm{SC}=\mathrm{SL}=1.5 \mathrm{~m} \sim 1.7 \mathrm{~m} \\
\mathrm{~L}=3.0 \mathrm{~m} ; \mathrm{SC}=\mathrm{SL}=2.5 \mathrm{~m}\end{array}$ & $\begin{array}{l}\mathrm{L}=2.5 \mathrm{~m} \\
\mathrm{SC}=\mathrm{SL}=1.5 \mathrm{~m}\end{array}$ \\
\hline$-1207.0 \mathrm{~m} \sim-1250.0 \mathrm{~m}$ & $\begin{array}{l}\mathrm{Q}=0.7 \\
\mathrm{RMR}=74\end{array}$ & $\begin{array}{l}\text { Simulation: } 2.08 \mathrm{~m} \\
\text { empirical method: } 3.66 \mathrm{~m}\end{array}$ & $\begin{array}{l}\mathrm{L}=3.2 \mathrm{~m} ; \mathrm{SC}=\mathrm{SL}=1.5 \mathrm{~m} \sim 1.7 \mathrm{~m} \\
\mathrm{~L}=3.0 \mathrm{~m} ; \mathrm{SC}=\mathrm{SL}=2.5 \mathrm{~m}\end{array}$ & $\begin{array}{l}\mathrm{L}=2.5 \mathrm{~m} \\
\mathrm{SC}=\mathrm{SL}=1.5 \mathrm{~m}\end{array}$ \\
\hline$-1250.0 \mathrm{~m} \sim-1271.0 \mathrm{~m}$ & $\begin{array}{l}\mathrm{Q}=0.6 \\
\mathrm{RMR}=70\end{array}$ & $\begin{array}{l}\text { Simulation: } 2.17 \mathrm{~m} \\
\text { empirical method: } 3.82 \mathrm{~m}\end{array}$ & $\begin{array}{l}\mathrm{L}=3.2 \mathrm{~m} ; \mathrm{SC}=\mathrm{SL}=1.5 \mathrm{~m} \sim 1.7 \mathrm{~m} \\
\mathrm{~L}=3.0 \mathrm{~m} ; \mathrm{SC}=\mathrm{SL}=2.5 \mathrm{~m}\end{array}$ & $\begin{array}{l}\mathrm{L}=2.5 \mathrm{~m} \\
\mathrm{SC}=\mathrm{SL}=1.5 \mathrm{~m}\end{array}$ \\
\hline
\end{tabular}

Fig. 9 Bolt supporting effect simulation in shaft-surrounding rock: a Bolt support without structural plane, b Bolt support with structural plane
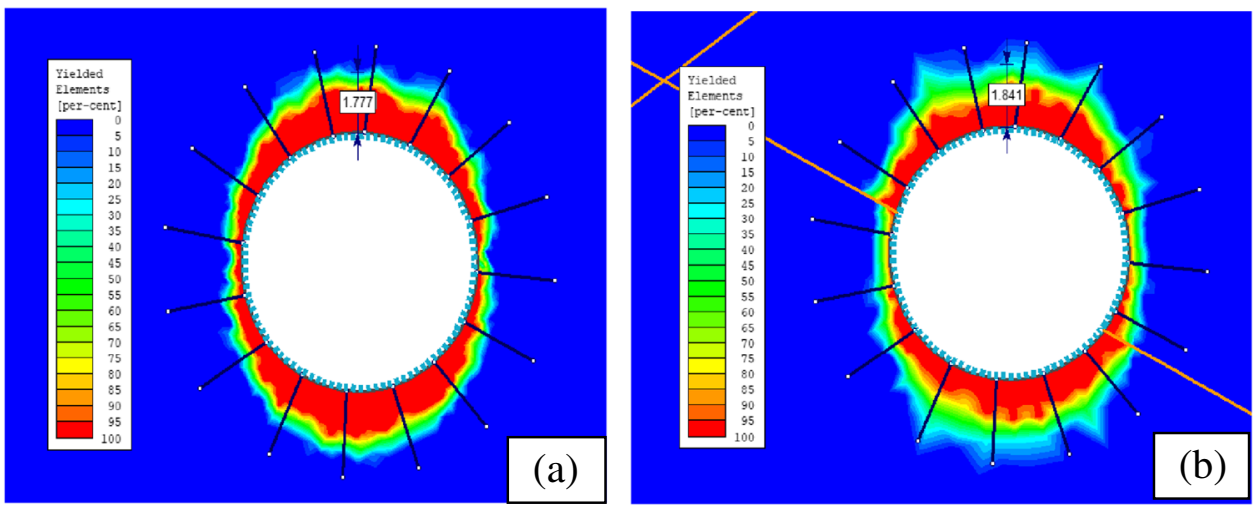

$u_{0}=\frac{\sin \phi}{2 G} a\left(p_{0}+c \cot \phi\right)\left[\frac{(1-\sin \phi)\left(p_{0}+c \cot \phi\right)}{p_{i}+c \cot \phi}\right]^{\frac{1-\sin \phi}{\sin \phi}}$

$\left\{\begin{array}{cc}p_{s}=K_{s}\left(u-u_{i}\right) & \text { elasticstage } \\ P_{s}=P_{s}^{\max } & \text { plasticstage }\end{array}\right.$

$\frac{u_{r}}{u_{r}^{M}}=\left[1+\exp \left(\frac{-x / R}{1.10}\right)^{-1.7}\right]$

where $u_{0}$ is the radial displacement of surrounding rock around shaft, $\mathrm{mm} ; G$ is the shear modulus of surrounding rock, $\mathrm{GPa} ; K_{s}$ is the stiffness of the support structure,
$\mathrm{MPa} / \mathrm{m} ; u_{i}$ is the initial shaft displacement when permanent support is installed, which can be determined by equilibrium point of interaction between the temporary support and surrounding rock, $\mathrm{mm} ; P_{s}$ is the bearing capacity of the support structure and $P_{s}^{\max }$ is its maximum bearing capacity, MPa; $u_{r}$ is the radial displacement of surrounding rock which has a distance from the working face of the shaft, $\mathrm{mm} ; u_{r}{ }^{M}$ is the corresponding maximum radial displacement, $\mathrm{mm}$.

As Fig. 11(a) shows, a horizontal line is drawn to intersect the deformation characteristic curve of surrounding rock by the maximum bearing capacity of the temporary support ( $P_{s}^{\max }$, then a vertical line is intersected the horizontal axis, $u_{0}$ is deformation for installing temporary support. When temporary support and surrounding rock reach balance, 
Fig. 10 Characteristic curve of interaction between surrounding rock and temporary support (a) Timing calculation diagram of permanent support (-1250 $\mathrm{m}$ to $-1271 \mathrm{~m})(\mathbf{b})$ (a)

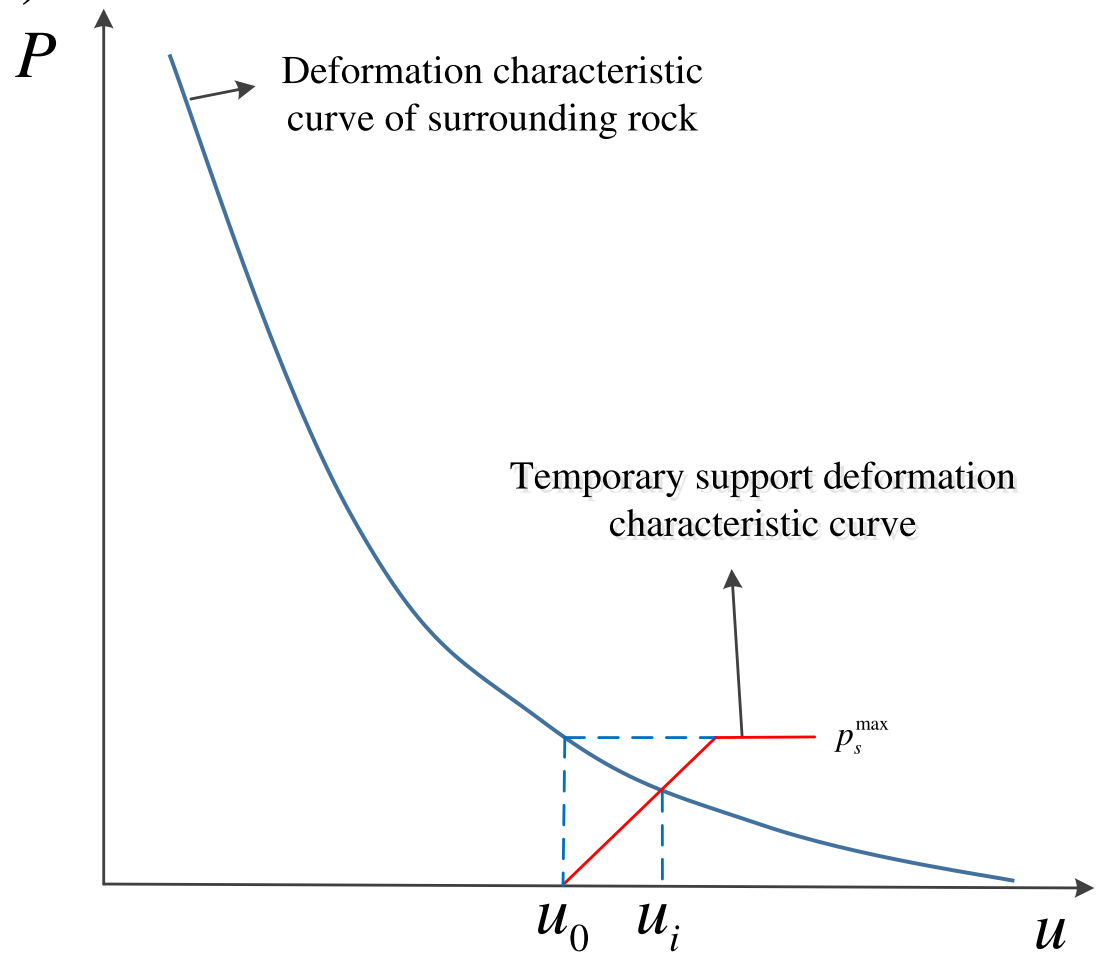

(b)

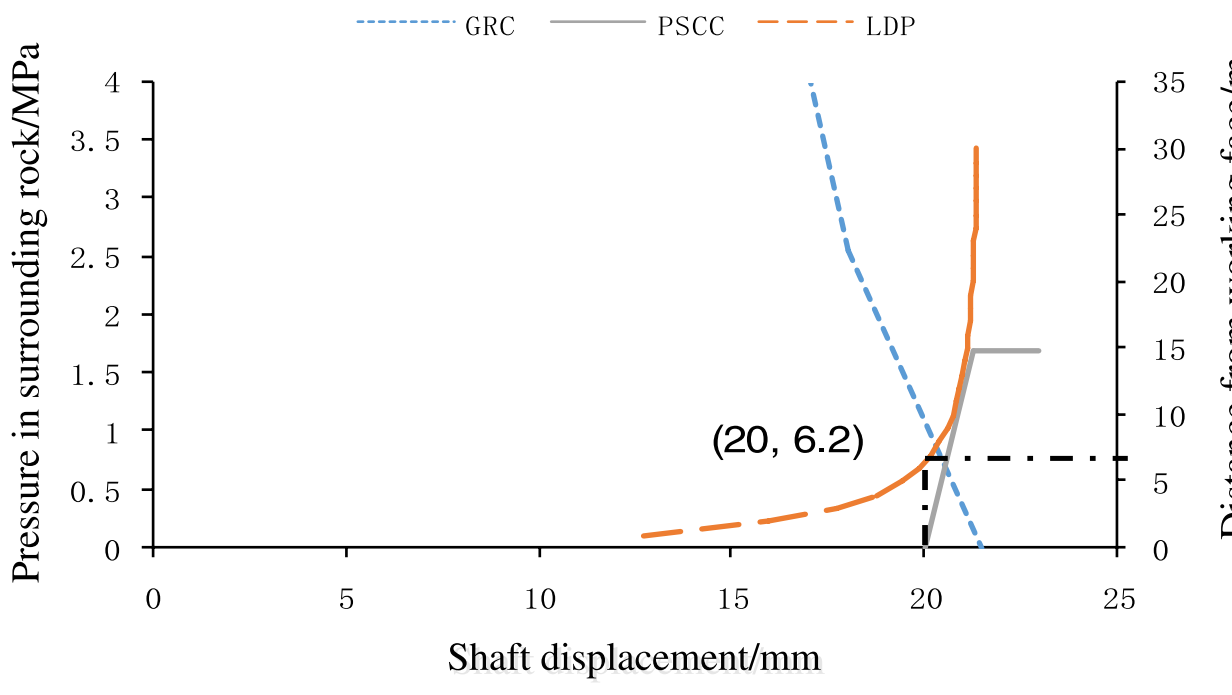

According to the permanent support timing calculation diagram, the required deformation of the surrounding rock and the height from the lining to working face in each construction section can be calculated as shown in Table 7 .

Table 7 shows that the minimum space requirement for pressure unloading from 930 to $1271 \mathrm{~m}$ depth should have an unsupported height from the lining to the working face greater than $4 \mathrm{~m}$, that is to say, 2 sinking cycles height $(8 \mathrm{~m})$ is needed during shaft excavation. Canadian shaft construction standards, conversely, suggest that the 
Fig. 11 Numerical model of simulated excavation schemes

\section{Scheme 1:Lining 4m per sinking cycle}

Scheme 2:Lining $4 \mathrm{~m}$ per

4 sinking cycle
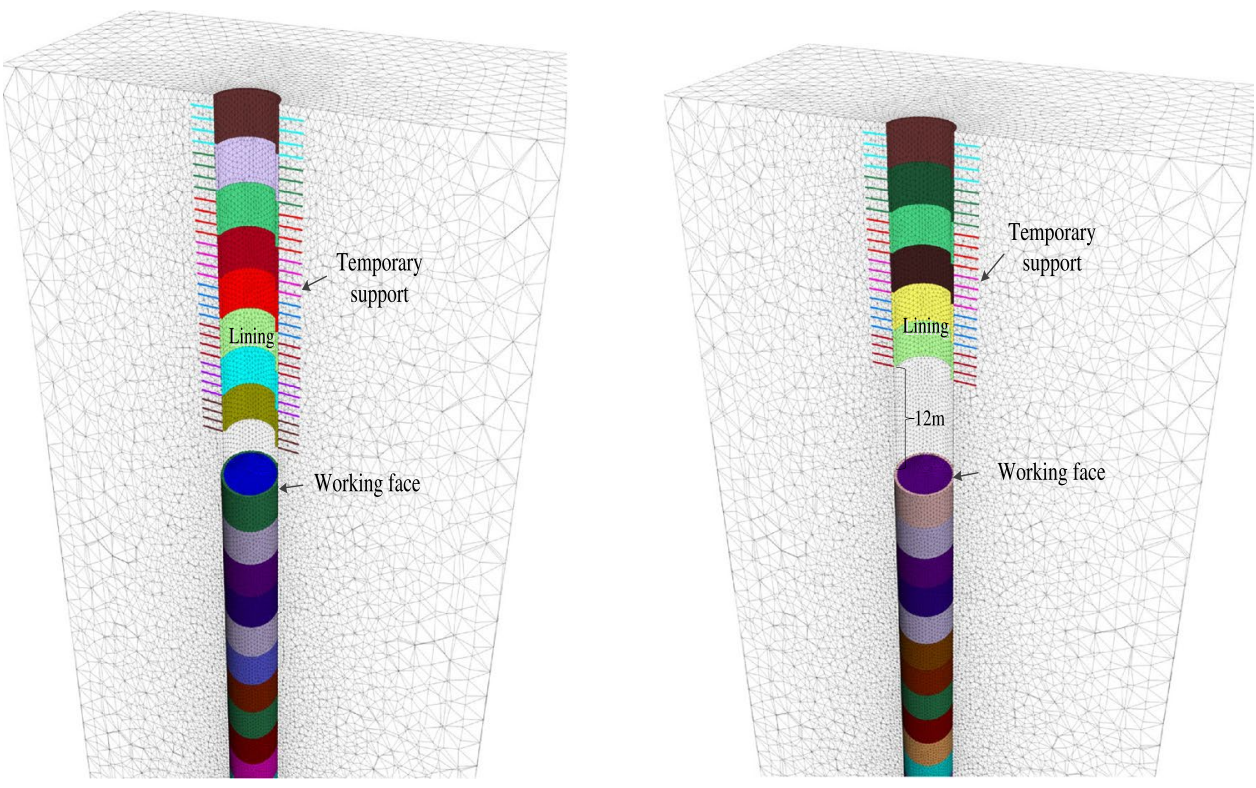

Table 7 Permanent support timing calculation results

\begin{tabular}{lll}
\hline $\begin{array}{l}\text { Construction } \\
\text { Section/m }\end{array}$ & $\begin{array}{l}\text { Required bench } \\
\text { height from working } \\
\text { face /m }\end{array}$ & $\begin{array}{l}\text { Required deformation } \\
\text { of surrounding rocks/ } \\
\mathrm{mm}\end{array}$ \\
\hline$-930 \sim-972$ & 5.9 & 11 \\
$-972 \sim-987$ & 5.9 & 11 \\
$-987 \sim-1050$ & 5.2 & 16.2 \\
$-1050 \sim-1073$ & 5.8 & 16.6 \\
$-1073 \sim-1102$ & 6 & 17 \\
$-1102 \sim-1153$ & 6.3 & 18 \\
$-1153 \sim-1207$ & 5.9 & 19 \\
$-1207 \sim-1250$ & 6.2 & 19.6 \\
$-1250 \sim-1271$ & 6.2 & 20 \\
\hline
\end{tabular}

span of surrounding rock with delayed permanent support should be $2-3$ times the shaft diameter over a construction time of about 4-6 days and 4-6 sinking cycles height. The surrounding rock stand-up time unsupported span analysis results based on RMR quality classifications and its stability chart indicate that an unsupported shaft height can reach 17-20 m with 4-5 sinking cycles height. Accordingly, the stress release time of the $-930 \mathrm{~m} \sim-972 \mathrm{~m}$ construction section was determined to be four sinking cycles and unsupported height to be $16 \mathrm{~m}$.

\section{Sequential stress control technology and its effect}

A numerical model was established based on the above temporary and permanent support parameters for the proposed sequential stress control technology. The simulation model was established in Flac3D with $70 \mathrm{~m} \times 70 \mathrm{~m} \times 300 \mathrm{~m}$, ranging from $-1050 \mathrm{~m}$ level to $-1350 \mathrm{~m}$ level, with $1,438,961$ elements. The initial stress boundary condition was applied after solving the stress tensor. Two simulation schemes were designed as shown in Table 8 to demonstrate the effects of stress control and safety improvement. The corresponding mechanical parameters are shown in Table 9.

As shown in Figs. 11, 12, 13, during sequential construction, the time for releasing stress and elastic strain energy in Scheme 1 is less than 1 cycle, and the stress is dynamic. In the horizontal direction, the stress reduction zone forms in the rock mass around the shaft and then transits to the stress increase zone. A high stress concentration zone forms in the unexcavated area under the working face in the vertical direction. In Scheme 2, 4 sinking cycles are necessary to release the stress and elastic strain energy during each sequential stress control process. There is a $12 \mathrm{~m}$ space from beginning to end that temporarily lacks permanent support.

Figures 12 and 13 show that in Scheme 2, the stress of the shaft and its adjacent area is significantly lower than that in Scheme 1. We set a stress monitoring line in the outer edge of the concrete lining above the shaft bottom to monitor changes in maximum principal stress distance from the shaft bottom. As shown in Fig. 14(a), there is 
Table 8 Simulated deep shaft excavation scheme

\begin{tabular}{lll}
\hline Construction technology & Simulated construction process & Stress boundary condition \\
\hline Scheme 1: the traditional & Step 1: excavation 4 m & initial sxx -34.649e6 grad 0 0 0.047e6 \\
short excavation and short & Step 2:temporary support & initial syy -18.035e6 grad 0 0 0.0294e6 \\
support & Step 3: Lining 4 m & initial szz -26.016e6 grad 0 0 0.028e6 \\
Scheme 2: delay support & Step 1: excavation 16 m & initial sxx -34.649e6 grad 0 0 0.047e6 \\
with sequential stress & Step 2: temporary support & initial syy -18.035e6 grad 0 0 0.0294e6 \\
control & Step 3: Lining 4 m & initial szz -26.016e6 grad 0 0 0.028e6 \\
\hline
\end{tabular}

\begin{tabular}{llllll}
\hline Construction Section/m & $\begin{array}{l}\text { Bulk modu- } \\
\text { lus /GPA }\end{array}$ & $\begin{array}{l}\text { Shear modu- } \\
\text { lus /GPA }\end{array}$ & Cohesion/MPa & $\begin{array}{l}\text { Inter friction } \\
\text { angle/ }\end{array}$ & $\begin{array}{l}\text { Tensile } \\
\text { strength/ } \\
\text { MPa }\end{array}$ \\
\hline$-930 \sim-972$ & 16.45 & 8.03 & 7.28 & 39.61 & 2.13 \\
$-972 \sim-987$ & 12.79 & 6.25 & 6.55 & 37.08 & 2.13 \\
$-987 \sim-1050$ & 13.43 & 6.20 & 6.55 & 37.08 & 2.13 \\
$-1050 \sim-1073$ & 12.79 & 6.25 & 6.55 & 37.08 & 2.39 \\
$-1073 \sim-1102$ & 12.79 & 6.25 & 6.55 & 37.08 & 2.39 \\
$-1102 \sim-1153$ & 12.79 & 6.25 & 6.55 & 37.08 & 2.41 \\
$-1153 \sim-1207$ & 12.79 & 6.25 & 6.55 & 37.08 & 2.41 \\
$-1207 \sim-1250$ & 12.79 & 6.25 & 6.55 & 37.08 & 2.74 \\
$-1250 \sim-1271$ & 12.79 & 6.25 & 6.55 & 37.08 & 2.74 \\
\hline
\end{tabular}

Table 9 Mechanical parameters for the numerical simulation models
Fig. 12 Evolution process of maximum principal stress during excavation (Scheme 1)

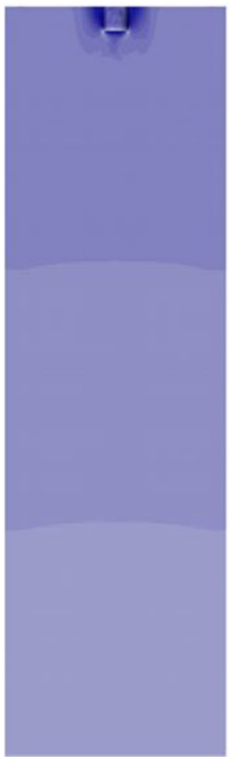

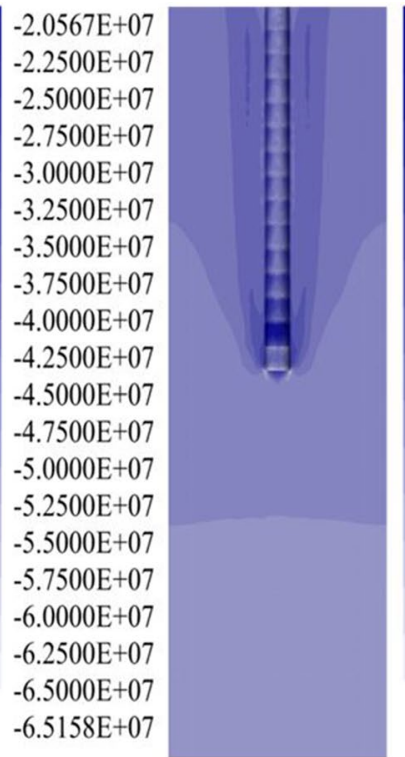

$-5.2184 \mathrm{E}+06$

$-1.0000 \mathrm{E}+07$

$-1.5000 \mathrm{E}+07$

$-2.0000 \mathrm{E}+07$

$-2.5000 \mathrm{E}+07$

$-3.0000 \mathrm{E}+07$

$-3.5000 \mathrm{E}+07$

$-4.0000 \mathrm{E}+07$

$-4.5000 \mathrm{E}+07$

$-5.0000 \mathrm{E}+07$

$-5.5000 \mathrm{E}+07$

$-6.0000 \mathrm{E}+07$

$-6.5000 \mathrm{E}+07$

$-7.0000 \mathrm{E}+07$

$-7.5000 \mathrm{E}+07$

$-7.7669 \mathrm{E}+07$

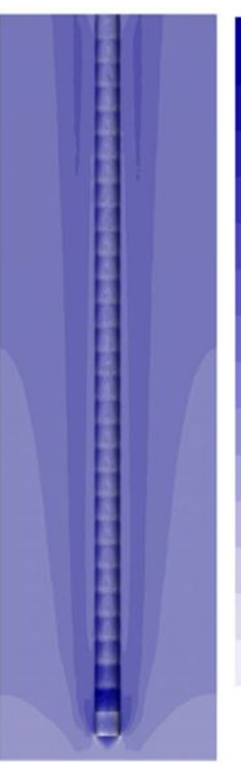

$-6.2367 \mathrm{E}+06$

$-1.0000 \mathrm{E}+07$

$-1.5000 \mathrm{E}+07$

$-2.0000 \mathrm{E}+07$

$-2.5000 \mathrm{E}+07$

$-3.0000 \mathrm{E}+07$

$-3.5000 \mathrm{E}+07$

$-4.0000 \mathrm{E}+07$

$-4.5000 \mathrm{E}+07$

$-5.0000 \mathrm{E}+07$

$-5.5000 \mathrm{E}+07$

$-6.0000 \mathrm{E}+07$

$-6.5000 \mathrm{E}+07$

$-7.0000 \mathrm{E}+07$

$-7.5000 \mathrm{E}+07$

$-7.7268 \mathrm{E}+07$ no obvious stress change; temporary support improves strength but is not conducive to stress reduction in the surrounding rock. However, Fig. 14(b) shows favorable stress-releasing effect after the construction technology is adjusted. Stress decreases sharply to a small value within $0-16 \mathrm{~m}$ of the shaft bottom. A location more than $16 \mathrm{~m}$ from the bottom, the stress in the concrete lining gradually converges to about $28 \mathrm{MPa}$. These observations are verified by Eq. (10)-(12).

$$
\begin{gathered}
\sigma_{r}^{c}=p_{i} \frac{a^{2}}{a^{2}-r_{i}^{2}}\left(1-\frac{r_{i}^{2}}{r^{2}}\right) \\
\sigma_{\theta}^{c}=p_{i} \frac{a^{2}}{a^{2}-r_{i}^{2}}\left(1+\frac{r_{i}^{2}}{r^{2}}\right)
\end{gathered}
$$


Fig. 13 Evolution process of maximum principal stress during excavation (Scheme 2)
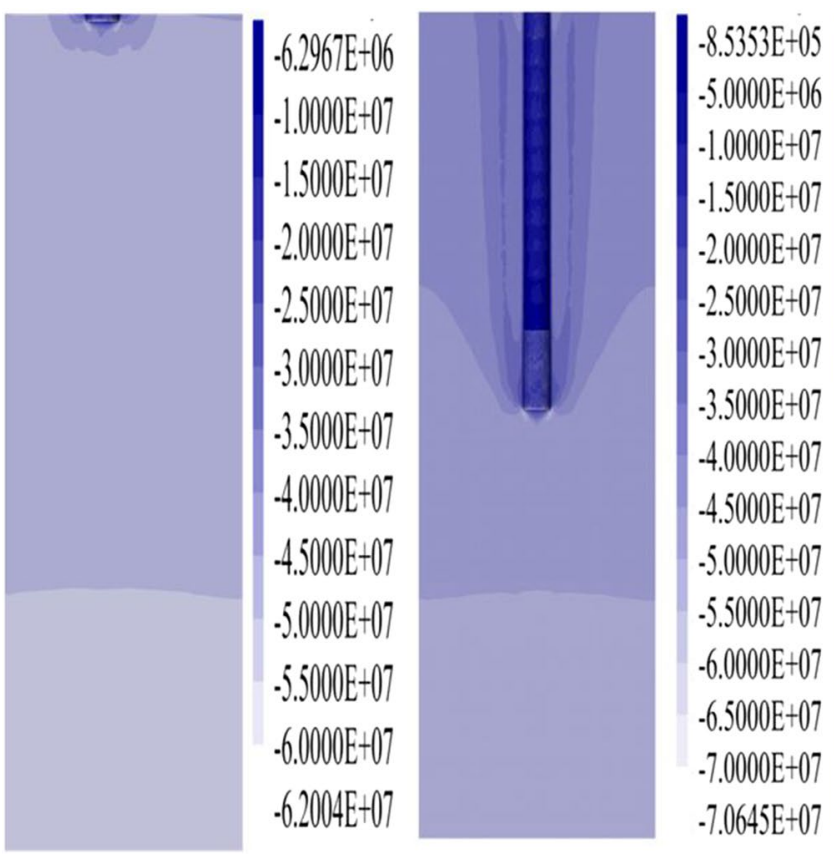

$-9.2289 \mathrm{E}+05$

$-5.0000 \mathrm{E}+06$

$-1.0000 \mathrm{E}+07$

$-1.5000 \mathrm{E}+07$

$-2.0000 \mathrm{E}+07$

$-2.5000 \mathrm{E}+07$

$-3.0000 \mathrm{E}+07$

$-3.5000 \mathrm{E}+07$

$-4.0000 \mathrm{E}+07$

$-4.5000 \mathrm{E}+07$

$-5.0000 \mathrm{E}+07$

$-5.5000 \mathrm{E}+07$

$-6.0000 \mathrm{E}+07$

$-6.5000 \mathrm{E}+07$

$-7.0000 \mathrm{E}+07$

$-7.0260 \mathrm{E}+07$
Fig. 14 Variation curve of maximum principal stress with distance from shaft bottom of concrete lining outer edge. a With versus without temporary support in traditional construction process. b Original technology versus improved technology

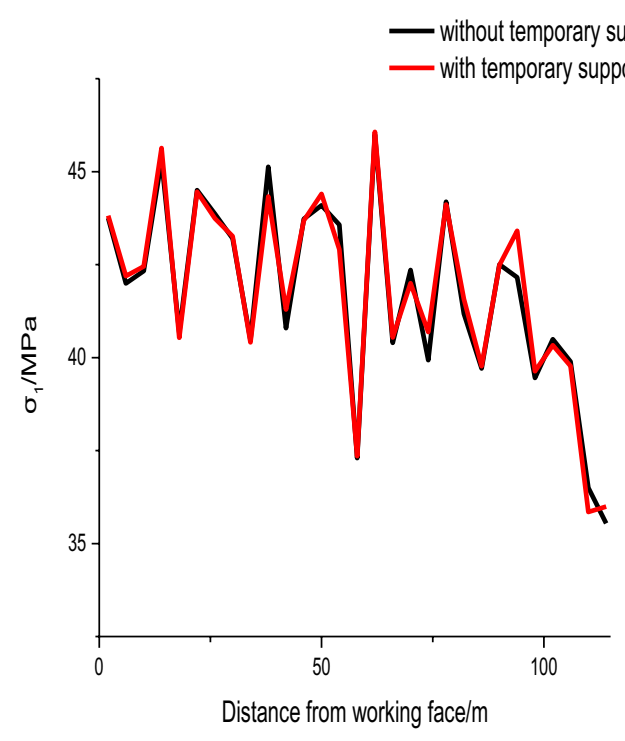

(a)

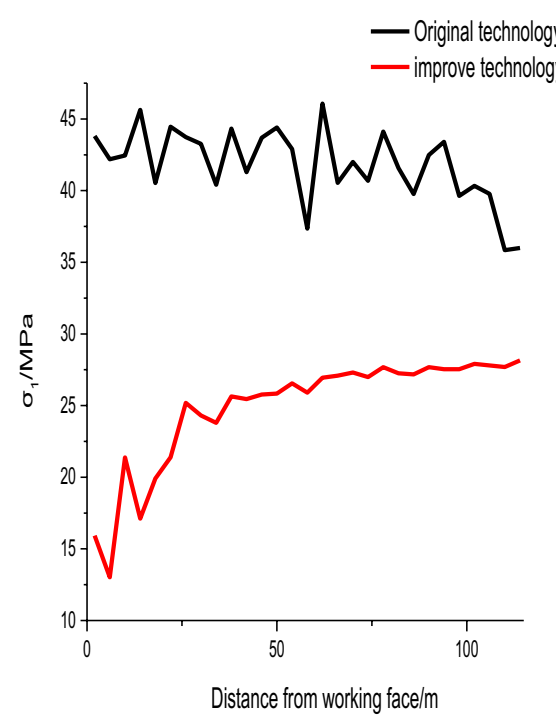

(b)

$$
F s=\frac{f_{c}^{\prime}}{\left(\frac{t}{r_{i}}+1\right)} / 2 p_{i}
$$

where $\sigma_{r}^{c}$ is radial stress in the lining, $\mathrm{MPa} ; \sigma_{\theta}{ }^{c}$ is tangential stress in the lining, $\mathrm{MPa} ; a$ is the radius of the shaft, $\mathrm{m} ; r_{i}$ is the internal radius of the concrete lining, $\mathrm{m} ; r$ is the distance from a point on the shaft to the center of the shaft, $\mathrm{m}$; $t$ is the concrete lining thickness, $\mathrm{m}$; $f c^{\prime}$ is the concrete's compressive strength, $\mathrm{MPa} ; p_{i}$ is the pressure from shaft-surrounding rock on the lining, $\mathrm{MPa} ; F S$ is the safety factor.
If $\sigma_{\theta}{ }^{c}=28 \mathrm{MPa}, a=3.75 \mathrm{~m}, r_{i}=3.35 \mathrm{~m}, r=3.35$, $t=0.4 \mathrm{~m}, f c^{\prime}=16.7 \mathrm{MPa}$, then $p_{i}=2.83 \mathrm{MPa}$ and $F S=2.35$, which can ensure the long-term safety of the lining.

\section{Conclusions}

High stress creates deformation, instability, and rockburst disasters during deep shaft construction in metal mines. The failure mode and failure zone shape of surrounding rock in a typical deep shaft construction process were 
analyzed in this study. A sequential stress control technology for deep shaft construction was developed accordingly. Corresponding temporary support and permanent support timing parameters were calculated and validated by theoretical analysis and numerical simulation. The main conclusions can be summarized as follows:

1) Rock surrounding the construction section of $-930 \mathrm{~m}$ to $-1271 \mathrm{~m}$ in the deep shaft is mild or severely squeezed strata under high stress. The potential failure mode is stress-controlled, and the failure zone of the surrounding rock is "ear" shaped. It is crucial to provide stress control to prevent high-stress disasters such as rock bursts.

2) Temporary support strengthens the rock mass, improves the shear capacity of surrounding rock, and prevents the broken rock from falling but does not release stress. The permanent support cannot bear the surrounding rock's stress but can only stabilize the rock mass. Therefore, the rock mass's stress and elastic strain energy should be released to the greatest extent possible before permanent support is installed; permanent support should not be installed too early.

3) Rock mass quality classification, RMR stability charts, and convergence-confinement theory information was combined to determine the time and height of delayed shaft permanent support as 4 days and $16 \mathrm{~m}$, respectively, during the construction of $-930 \mathrm{~m}$ to $-1271 \mathrm{~m}$. Numerical simulation and safety factor proof information indicate that sequential stress control technology can reduce the stress in the surrounding rock and ensure long-term shaft stability. But when the excavation depth increases, it should further study and adjust the stress releasing time and space in time.

4) The proposed sequential stress control technology may be a valuable reference for excavating hard rock deep shafts in metal mines. Our results also suggest that stress and deformation monitoring during construction should be strengthened.

Acknowledgements This study was sponsored by the National Key R\&D Program of the 13th Five-Year Plan (Grant No. 2016YFC0600800). The authors would also like to thank the reviewers for their valuable comments and suggestions.

Open Access This article is licensed under a Creative Commons Attribution 4.0 International License, which permits use, sharing, adaptation, distribution and reproduction in any medium or format, as long as you give appropriate credit to the original author(s) and the source, provide a link to the Creative Commons licence, and indicate if changes were made. The images or other third party material in this article are included in the article's Creative Commons licence, unless indicated otherwise in a credit line to the material. If material is not included in the article's Creative Commons licence and your intended use is not permitted by statutory regulation or exceeds the permitted use, you will need to obtain permission directly from the copyright holder. To view a copy of this licence, visit http://creativecommons.org/licenses/by/4.0/.

\section{References}

Arshadnejad S (2019) Design of hole pattern in static rock fracture process due to expansion pressure. Int J Rock Mech Min Sci 123:104100. https://doi.org/10.1016/j.ijrmms.2019.104100

Barton N (1978) Recent experiences with the Q-system of tunnel engineering support design. Field Tests

Barton N, Line R, Lunde J (1974) Engineering classification of rock masses for the design of tunnel support. Roc Mec 6(4):189-326

Bhasin R, Grimstad E (1996) The use of stress-strength relationships in the assessment of tunnel stability[J]. Tunn Undergr Space Technol 11(1):93-98. https://doi.org/10.1016/0886-7798(95)00047-X

Bieniawski ZT (1989) Engineering rock mass classification. Wiley, New York

Ge BF (2020) Field evaluation of flexible support system with radial gap (fsrg) under a squeezing rock condition in a coal mine development. Geomech Geophys Geo-Energy Geo-Resour 6(3):168268. https://doi.org/10.1007/s40948-020-00175-9

Huang LL, Wang GW, Carranza EJM et al (2020) Multi-scale numerical simulation and 3D modeling for deep mineral exploration in the Jiaojia gold district. China J Nat Resour Res 29(1):415-438. https://doi.org/10.1007/s11053-019-09608-z

Jiang Q, Feng XT, Xiang TB, Su GS (2010) Rockburst characteristics and numerical simulation based on a new energy index: a case study of a tunnel at 2,500 m depth. Bull Eng Geol Environ 69:381-388. https://doi.org/10.1007/s10064-010-0275-1

Kaya A, Tarak UC (2021) Stability investigation of a deep shaft using different methods. Int J geomech 21(2):05020009. https://doi.org/ 10.1061/(ASCE)GM.1943-5622.0001917

Li GF, Tao ZG, Guo HG, Ping QI, Guo ZB (2010) Stability control of a deep shaft insert. Int J Min Sci Technoly 20(4):491-498. https:// doi.org/10.1016/S1674-5264(09)60231-3

Li Y, Zhao YX, Wang C, Li XH (2013) Study on characteristic and mechanism of deformation and failure of roadway surrounding rock in deep mining. Adv Mat Res 734-737:819-823. https://doi. org/10.4028/www.scientific.net/AMR.734-737.819

Li B, Ding QF, Xu NW, Lei YF, Xu Y, Zhu ZP, Liu JF (2020) Mechanical response and stability analysis of rock mass in high geostress underground powerhouse caverns subjected to excavation. J Cent South Univ 27(10):2971-2984. https://doi.org/10.1007/ s11771-020-4522-8

Lin D, Wang K, Li K, He WT, Bao WX, Yuan RM, Shang YJ (2017) Modification of rock mass strength assessment methods and their application in geotechnical engineering. Bull Eng Geol Environ 76:1471-1480. https://doi.org/10.1007/s10064-016-0952-9

Manuel DLF, Taherzadeh R, Sulem NX, Subrin D (2019) Applicability of the convergence-confinement method to full-face excavation of circular tunnels with stiff support System. Rock Mech Rock Eng 52(7):2361-2376. https://doi.org/10.1007/s00603-018-1694-8

Martin CD, Chandler NA (1994) The progressive fracture of Lac du Bonnet granite. Int J Rock Mech Min Sci 31(6):643-659

Martin CD, Kaiser PK, McCreath DR (1999) Hoek-Brown parameters for predicting the depth of brittle failure around tunnels. Canada Geotech J 36:136-151

Mishra RK, Janiszewski M, Uotinen LKT, Szydlowska M, Siren T, Rinne M (2017) Geotechnical risk management concept for intelligent deep mines. Procedia Eng 191:361-368. https://doi.org/10. 1016/j.proeng.2017.05.192 
Rahim IA, Mohamad MSN (2019) Tunnel support by rock quality index $(\mathrm{Q})$ system for ultrabasic rock: a case study in Telupid, Sabah, Malaysia. Geolo B 3(2):1-5. https://doi.org/10.26480/ gbr.02.2019.01.05

Ren FQ, Chang Y, He MC (2020) A systematic analysis method for rock failure mechanism under stress unloading conditions: a case of rock burst. Environ Earth Sci 79(15):289-303. https://doi.org/ 10.1007/s12665-020-09111-2

Sun QH, Ma FS, Guo J, Li G, Feng XL (2020) Deformation failure mechanism of deep vertical shaft in Jinchuan mining area. Sustainability 12(6):2226. https://doi.org/10.3390/su12062226

Wagner H (2019) Deep Mining: a rock engineering challenge, rock mechanics and rock engineering. Rock Mech Rock Eng 52(5):1417-1446. https://doi.org/10.1007/s00603-019-01799-4

Walton G, Kim E, Sinha S, Sturgis G, Berberick D (2018) Investigation of shaft stability and anisotropic deformation in a deep shaft in Idaho, United States. Int J Rock Mech Min Sci 105:160-171. https://doi.org/10.1016/j.ijrmms.2018.03.017

Yao Z, Zhang P, Cheng H et al (2020) Testing of a dual-steel-plate-confined high-performance concrete composite shaft lining structure and its application. Appl Sci 10(8):2938. https://doi.org/10.3390/ app 10082938

Yi K, Liu ZH, Lu ZG, Zhang JW, Sun ZY (2020) Transfer and dissipation of strain energy in surrounding rock of deep roadway considering strain softening and dilatancy. Energy Sci Eng 9(1):27-39. https://doi.org/10.1002/ESE3.811

Zhang YH (2018) Numerical simulation study on mechanical response of tunnel dynamic construction. IOP Conf Ser Earth Environ Sci 189(5):052019. https://doi.org/10.1088/1755-1315/189/5/052019

Zhang CG, Wang JF, Zhao JH (2010) Unified solutions for stresses and displacements around circular tunnels using the Unified Strength Theory. Sci China Technol Sci 53(6):1694-1699. https://doi.org/ 10.1007/s11431-010-3224-0

Zhou H, Meng FZ, Zhang CQ, Hu DW, Yang FJ, Lu JJ (2015) Analysis of rockburst mechanisms induced by structural planes in deep tunnels. B Eng Geol Environ 74(4):1435-1451. https://doi.org/ 10.1007/s10064-014-0696-3 